\title{
Effect of silicon and acibenzolar-s-methyl on colored cotton plants infested or not with Aphis gossypii Glover (Hemiptera, Aphididae)
}

\author{
Eliana Alcantra ${ }^{1}$, Jair Campos Moraes ${ }^{1}$, Alex Antonio $^{2}$, Roberta Alvarenga ${ }^{1} \&$ Jonas Françoso $^{1}$
}

\begin{abstract}
'Departamento de Entomologia, Universidade Federal de Lavras, Caixa Postal 3037, 37200-000 Lavras-MG, Brasil. lialcantra@yahoo.com.br; jcmoraes@den.ufla.br; rolavras@yahoo.com.br; jonasfrancoso@hotmail.com

${ }^{2}$ Departamento de Genética e Melhoramento de Plantas, Universidade Federal de Lavras, Caixa Postal 3037, 37200-000 Lavras-MG, Brasil. alex_nepre@yahoo.com.br
\end{abstract}

\begin{abstract}
Effect of silicon and acibenzolar-s-methyl on colored cotton plants infested or not with Aphis gossypii Glover (Hemiptera, Aphididae). The aphid Aphis gossypii is an insect pest that causes damage mainly at the beginning of the cotton plant development. The effect of resistance inductors silicon and acibenzolar-s-methyl (ASM) on the development of colored cotton plants were researched in the presence and absence of $A$. gossypii. Three colored cotton cultivars were sown in pots and individually infested with 25 apterous aphids, 13 days after the application of the inductors. Fifteen days after plant emergence, the silicon was applied at a dosage equivalent to $3 \mathrm{t} / \mathrm{ha}$ and acibenzolar-s-methyl in $0.2 \%$ solution of the product BION $500^{\circledR}$. After 21 days of infestation the following parameters were evaluated: plant height, stem diameter, dry matter of aerial part and root, and total number of aphids replaced. It was verified that the plant height was reduced in the presence of aphids and all variables were negatively affected by the application of ASM. However, silicon did not affect plant development.
\end{abstract}

KEYWORDS. Colored fibers; cotton aphid; inductors; IPM; plant resistance.

RESUMO. Efeito do silício e do acibenzolar-s-methyl em plantas de algodão colorido infestadas ou não com Aphis gossypii Glover (Hemiptera, Aphididae). O pulgão Aphis gossypii é um inseto-praga que causa danos principalmente no início do ciclo do algodoeiro. Foram pesquisados os efeitos dos indutores silício e acibenzolar-s-methyl (ASM) no desenvolvimento de plantas de algodão colorido, na presença e ausência de A. gossypii. Três cultivares de algodão colorido foram semeadas em vasos e individualmente infestadas com 25 pulgões ápteros, 13 dias após a aplicação dos indutores. Quinze dias após emergência das plantas o silício foi aplicado na dosagem equivalente a 3 t/ha e o acibenzolar-s-methyl (ASM) na solução $0,2 \%$ do produto BION $500^{\circledR}$. Após 21 dias da infestação foram avaliados os seguintes parâmetros: altura da planta, diâmetro do caule, massa seca da parte aérea e da raiz, e o número total de pulgões repostos. Verificou-se que apenas a altura das plantas foi reduzida pela presença do pulgão e que todas as variáveis estudadas foram afetadas negativamente pela aplicação do ASM, porém não se observou efeito negativo do silício no desenvolvimento das plantas.

PALAVRAS-CHAVE. Fibras coloridas; indutores; MIP; pulgão-do-algodoeiro; resistência de plantas.

Products such as fibers, threads, cloth and clothing obtained from the naturally colored cotton have been sought after in the domestic as well as the external market, especially in European countries. In order to develop new cultivars with naturally colored fibers, genetic improvement programs were initiated about 15 years ago, simultaneously in Brazil, United States, and Israel. In Brazil, the program was developed by Embrapa Cotton, headquartered in Campina Grande, Paraíba, using plants derived by selection from the arboreal moco cotton (Gossypium hirsutum L. var. marie-gallante Hutch.) (Beltrão et al. 2003). The main advantage of employing the colored fiber is the elimination of the use of dyes during the fabric finishing stage, which reduces the environmental impact of the dyeing process, being appropriate for production of ecological and organic fabrics (Souza 2000).

Colored fiber cotton is infested by the same insect pests that attack conventional cotton cultivars (Beltrão et al. 2003) and the cotton aphid, Aphis gossypii Glover, 1877 (Hemiptera, Aphididae), is one of the most common pest species. In addition to transmitting viruses, these aphids cause damage by sap sucking and production of honeydew that favors sooty mold development, compromising leaf respiration and photosynthesis. When the insects occur in the final developmental stage of the culture, they depreciate the quality of the fiber by the excessive production of honeydew, affecting its industrial use (Santos et al. 2003).

The degree of plant resistance against insects can be increased by the application of resistance inductors. Studies have demonstrated that the application of inductors such as silicon and/or acibenzolar-s-methyl (ASM) promotes an increase in the protection of the plant against abiotic and biotic stresses, due to the mechanical barrier formed by the silica deposition in the foliar tissues and in the trichomes, and also by the production of phenolic defense compounds (Inbar et 
al. 2001; Gomes et al. 2008). However, little is known about the development of the cotton plant when treated with those products.

Therefore, this research was conducted in order to obtain more information on the effects of silicon and ASM, in the presence and absence of the aphid A. gossypii, on the development of colored cotton plants.

The experiments were conducted in a greenhouse, in the Department of Entomology, Federal University of Lavras, Lavras, MG, with colored cotton of cultivars BRS Verde, BRS Safira and BRS Rubi.

Initially, the number of insects ( 25 aphids/plant) necessary to cause significant damage in susceptible plants was determined, according to the methodology proposed by Cruz $\&$ Vendramim (1998). For the definitive assay, six seeds of each cultivar were planted in $2 \mathrm{~kg}$ capacity pots with substrate composed of soil and corral manure at a proportion of $3: 1$. After emergence, only one plant per pot was kept. Each pot was covered with a voil cage fixed with a rubber band $(60 \mathrm{~cm} \times 36 \mathrm{~cm})$ and sustained with wooden sticks.

The experimental design was entirely random, in a factorial outline; 3 treatments (control, silicon and ASM) x 3 cultivars (BRS Verde, BRS Rubi and BRS Safira) x 2 aphid infestation (with and without infestation) and 10 replicates. The pots were randomly placed on benches, with 60 pots (replicates) per cultivar.

Fifteen days after plant emergence, 2\% silicic acid solution was applied at a dosage equivalent to $3 \mathrm{t}$ of $\mathrm{SiO}_{2} /$ ha and $0.2 \%$ ASM of the commercial product BION $500^{\circledR}$. The silicic acid solution was applied around the seedlings and that of ASM applied through manual spraying until dripping. The control pots received water in the same amount, but no inductors.

Thirteen days after the silicon and ASM applications, half of the pots of each treatment were infested with apterous adults $A$. gossypii at a density of 25 aphids/plant. The other half was not infested with aphids, allowing comparing the development of the plant in the presence and absence of $A$. gossypii. After the infestation, daily observations were made, removing nymphs and replacing dead or disappeared adult aphids in order to maintain the initial population number. The counting of the number of adult aphids replaced/treatment was done in order to evaluate the effect of the inductors on the aphid.

After 21 days of aphid release, when it was possible to observe a difference among the development of the infested and non-infested plants, plant height was evaluated (distance between base and apex) and the diameter of the stem at $5 \mathrm{~cm}$ from the soil. Later, the plants were cut close to the soil, and the foliage was conditioned in paper bags and placed in an oven at $60^{\circ} \mathrm{C}$ to stabilize the mass, determining the dry matter of the aerial part. Afterwards, the substrate from the pots was poured on a plastic sieve and the roots were separated using running water and placed on filter paper to remove excess of moisture. The determination of the dry matter was similar to that of the aerial part.
The data was submitted to ANOVA (the variance analysis) and means compared by F and Tukey tests both at $\mathrm{p} \leqslant 0.05$. The number of replaced aphids was transformed in $\sqrt{x+0.5}$ before the analysis.

It was observed that there was no effect of the interaction among aphid infestation, cultivar and resistance inductor factors. However, it was possible to verify isolated effects of these factors for some plant characteristics.

When evaluating the influence of plant infestation with A. gossypii, a significant effect was observed on plant height, which was reduced by the presence of aphid compared to non-infested plants. The other variables studied did not present significant differences (Table I). Similar results were obtained by Vendramin \& Nakano (1981) that verified a reduction in height of white cotton cv. IAC-17 plants due to the presence of $A$. gossypii. However, those authors observed that $A$. gossypii was capable of reducing the dry matter weight of cotton plants, which was not verified in the present work.

Evaluating different cultivars it was verified that the diameter and dry mass of aerial part of cv. Safira was similar to that of Verde and Rubi cultivars and the height did not differ significantly among cultivars. However, cv. Verde presented larger stem diameter and higher dry mass of aerial part and root than cvs. Rubi and Safira (Table I). Those differences are related to the particular agronomic characteristics of the cultivar. However, studies on several crops evidenced differences among cultivars regarding those characteristics (Faria Júnior et al. 2009; Moraes et al. 2009).

When the colored cotton plants received applications of inductors it was verified that ASM significantly reduced all parameters compared with the control and the silicon treatment. Between silicon and control there was no significant difference concerning the development of the cotton plants (Table I).

Table I. Mean ( \pm EP) height, stem diameter, dry matter of aerial part $(\mathrm{ADM})$ and dry matter of roots (RDM) of colored cotton cultivars treated with silicon or acibenzolar-s-methyl (ASM), infested or not with Aphis gossypii, at 21 days after infestation. Lavras-MG.

\begin{tabular}{ccccc}
\hline Aphid & $\begin{array}{c}\text { Height } \\
(\mathrm{cm})\end{array}$ & $\begin{array}{c}\text { Stem diameter } \\
(\mathrm{mm})\end{array}$ & $\begin{array}{c}\text { ADM } \\
(\mathrm{g})\end{array}$ & $\begin{array}{c}\text { RDM } \\
(\mathrm{g})\end{array}$ \\
\hline Without & $59.2 \pm 1.04 \mathrm{a}^{*}$ & $5.8 \pm 0.12$ & $7.0 \pm 0.00$ & $1.2 \pm 0.06$ \\
With & $46.1 \pm 1.22 \mathrm{~b}$ & $6.1 \pm 0.14$ & $7.0 \pm 0.00$ & $1.3 \pm 0.06$ \\
Cultivar & & & & \\
Verde & $54.7 \pm 1.80$ & $6.4 \pm 0.16 \mathrm{a}^{* *}$ & $8.0 \pm 0.00 \mathrm{a}^{* *}$ & $1.4 \pm 0.08 \mathrm{ab}^{* *}$ \\
Safira & $52.0 \pm 2.14$ & $5.9 \pm 0.16 \mathrm{ab}$ & $7.0 \pm 0.00 \mathrm{ab}$ & $1.2 \pm 0.07 \mathrm{~b}$ \\
Rubi & $51.2 \pm 1.49$ & $5.5 \pm 0.14 \mathrm{~b}$ & $6.0 \pm 0.00 \mathrm{~b}$ & $1.2 \pm 0.06 \mathrm{~b}$ \\
Inductor & & & & \\
Silicon & $57.0 \pm 1.65 \mathrm{a}^{* *}$ & $6.3 \pm 0.15 \mathrm{a} * *$ & $8.0 \pm 0.00 \mathrm{a}^{* *}$ & $1.4 \pm 0.06 \mathrm{a} * *$ \\
ASM & $46.2 \pm 1.84 \mathrm{~b}$ & $5.5 \pm 0.16 \mathrm{~b}$ & $6.0 \pm 0.00 \mathrm{~b}$ & $1.0 \pm 0.07 \mathrm{~b}$ \\
Control & $54.9 \pm 1.39 \mathrm{a}$ & $6.1 \pm 0.15 \mathrm{a}$ & $8.0 \pm 0.00 \mathrm{a}$ & $1.4 \pm 0.07 \mathrm{a}$ \\
\hline CV (\%) & 10.81 & 12.81 & 35.32 & 26.72 \\
\hline
\end{tabular}

Means followed by different lowercase letters in the column for aphid, cultivar or inductor, differ statistically among themselves for the $\mathrm{F}(*)$ and Tukey $(* *)$ tests both at $\mathrm{p} \leqslant 0.05$. 
There was no influence of the cultivar and of the inductors on the number of replaced aphids in the plants (Table II).

Table II. Total number of aphids replaced on different colored cotton cultivars treated and non-treated with silicon or acibenzolar-s-methyl (ASM) keeping the density of 25 adult aphids/plant.

\begin{tabular}{lc}
\hline \multicolumn{1}{c}{ Cultivar } & Number of replaced aphids * \\
\hline Verde & $48.33 \pm 3.64$ \\
Safira & $46.47 \pm 3.67$ \\
Rubi & $51.13 \pm 3.89$ \\
Inductor & \\
Silicon & $45.27 \pm 3.79$ \\
ASM & $54.73 \pm 3.16$ \\
Control & $45.93 \pm 3.78$ \\
\hline CV $=15.16 \%$ & \\
\hline
\end{tabular}

*Means not significant by the F test $(\mathrm{p} \leqslant 0.05)$.

Reduction in growth of colored cotton plants by the application of ASM can be due to the action of some compounds in the cellular wall that affect cellular elongation. According to Boudet (1998), growth inhibition is associated with deposition of lignin on the extensibility of the primary cell wall, affecting cellular elongation.

Differing from the present work, Boughton et al. (2006) and Cavalcanti et al. (2006) did not verify significant effect on growth of tomato plants caused by the application of ASM. Costa et al. (2007) did not observe any effect of ASM on dry mass of the aerial part of wheat plants.

Accumulation of silicon on stem tissues substantially strengthens the structure of the plant increasing plant diameter (Plucknett 1971). However, that effect was not observed in the colored cotton plants compared with corn plants, in which the diameter increases due to silicon application (Neri et al. 2009).

Among other benefits of silicated fertilization there is an increase in phytomass of foliage and roots and, consequently in plant growth (Epstein 1994, 1999). However, those benefits were not observed in the colored cotton plants, probably due to the fact that the cotton plant is considered a non-silicon accumulator plant. Similar results were found in potato plants (Gomes et al. 2008, 2009), wheat plants (Costa et al. 2007) and rice (Silva \& Bohnem 2001; Tokura et al. 2007), in which there was no influence of silicon.

Comparing the production of colored and white cotton plants Nóbrega et al. (2007) did not observe any effect related to the cultivar when increasing levels of silicon applied in the soil, similar to our findings.

It can be concluded that cotton plants are affected by infestation with $A$. gossypii and by application of acibenzolar-smethyl (ASM), whereas silicon does not affect plant development.

\section{ACKNOWLEDGMENTS}

To Conselho Nacional de Desenvolvimento Científico e Tecnológico - CNPq for financial support and to Fundação de Amparo à Pesquisa de Minas Gerais - FAPEMIG for grants.

\section{REFERENCES}

Beltrão, N. E. M.; J. R. Pereira; G. D. Cardoso \& L. S. Soares. 2003. Sistema de produção para o algodão colorido BRS 200 Marrom para a agricultura familiar no Cerrado do Mato Grosso, com ênfase para a adubação. Campina Grande, EMBRAPA- CNPA, 8 p. (Circular Técnica 71).

Boudet, A. M. 1998. A new view of lignification. Trends in Plant Science 3: $67-71$.

Boughton, A. J.; K.; K. Hoover \& G. W. Felton. 2006. Impact of chemical elicitor applications on Verdehouse tomato plants and population growth of the green peach aphid, Myzus persicae. Entomologia Experimentalis et Applicata 120: $175-188$.

Cavalcanti, F. R.; M. L. V. Resende; A. B. Zacaroni; P. M. Ribeiro Junior; J. de C. B. Costa \& R. M. Souza. 2006. Acibenzolar-S-Metil e Ecolife $\mathbb{R}$ na indução de respostas de defesa do tomateiro contra a mancha bacteriana (Xanthomonas vesicatoria). Fitopatologia Brasileira 31: $372-380$.

Costa, R. R; J. C. Moraes \& C. S. Antunes. 2007. Resistência induzida em trigo ao pulgão Schizaphis graminum (Rondani, 1852) (Hemiptera: Aphididae) por silício e acibenzolar-S-methyl. Ciência e Agrotecnologia 31: 393-397.

Cruz, I \& J. D. Vendramim. 1998. Tolerância como mecanismo de resistência de sorgo ao pulgão Schizaphis graminum (Rond.) (Homoptera: Aphididae). Anais da Sociedade Entomológica do Brasil 27: 141148.

Epstein, E. 1994. The anomaly of silicon in plant biology. Proceedings of the National Academy of Science USA 91: 11-17.

Epstein, E. 1999. Silicon. Annual Review of Plant Physiology and Plant Molecular Biology 50: 641-664.

Faria Júnior, L. A.; J. G. Carvalho; P. J. Pinho; A. R. R. Bastos \& E. V. O. Ferreira. 2009. Produção de matéria seca, teor e acúmulo de silício em cultivares de arroz sob doses de silício. Ciência e Agrotecnologia 33: 1034-1040.

Gomes F. B.; J. C. Moraes \& G. A. Assis. 2008. Silício e imidacloprid na colonização de plantas por Myzus persicae e no desenvolvimento vegetativo de batata inglesa. Ciência Rural 38: 1209-1213.

Gomes, F. B.; J. C. Moraes \& D. K. P. Neri. 2009. Adubação com silício como fator de resistência a insetos-praga e promotor de produtividade em cultura de batata inglesa em sistema orgânico. Ciência e Agrotecnologia 33: 18-23.

Inbar, M.; H. Doostdar; D. Gerling \& R. T. Mayer. 2001. Induction of systemic acquired resistance in cotton by BTH has a negligible effect on phytophagous insects. Entomologia Experimentalis et Applicata 99: $65-70$.

Moraes, J. C.; R. S. Ferreira \& R. R. Costa. 2009. Indutores de resistência à mosca-branca Bemisia tabaci biótipo B (Genn., 1889) (Hemiptera: Aleyrodidae) em soja. Ciência e Agrotecnologia 33: 1260-1264.

Neri, D. K. P.; F. B. Gomes; J. C. Moraes; G. B. Góes \& S. T. P. Marrocos. 2009. Influência do silício na suscetibilidade de Spodoptera frugiperda (J. E. Smith) (Lepidoptera: Noctuidae) ao inseticida lufenuron e no desenvolvimento de plantas de milho. Ciência Rural 39: 1633-1638.

Nóbrega, J. A. da; L. B. Madeiros; G. C. G. Neto; R. G. Nobre; J. D. Neto \& J. D. C. de. Oliveira. 2007. Produção do algodoeiro adubado com escória siderúrgica, Revista Educação Agrícola Superior 22: 51-53.

Plucknett, D. L. 1971. The use of soluble silicates in Hawaii agriculture. University of Queensland 1: 203-223.

Santos, T. M.; A. L Boiça-Junior \& J. J. Soares. 2003. Influencia de tricomas 
do algodoeiro sobre os aspectos biológicos e capacidade predatória de Chrysoperla externa (Hagen) alimentada com Aphis gossypii Glover. Bragantia 62: 243-254.

Silva, L. S. \& H. Bohnen. 2001. Rendimento e acúmulo de nutrientes pelo arroz em solução nutritiva com e sem adição de silício. Revista Brasileira de Ciência do Solo 25: 771-777.

Souza, M. C. M. 2000. Produção de algodão orgânico colorido: possibili- dade e limitações. Informações Econômicas 30: 91-98.

Tokura, A. M.; A. E. Furtini Neto; N. Curi; L. F. Carneiro \& Alovisi, A. A. 2007. Silício e fósforo em diferentes solos cultivados com arroz de sequeiro. Acta Scientiarum Agronomy 29: 9-16.

Vendramim, J. D. \& O. Nakano. 1981. Avaliação de danos de Aphis gossypii Glover, 1877 (Homoptera: Aphididae) no algodoeiro cultivar 'IAC-17'. Anais da Sociedade Entomológica do Brasil 10: 89-96. 